Jurnal Ekonomi dan Perbankan Syariah

Vol. 8. No.2, 0ktober 2020: 91-109, ISSN (cet): 2355-1755 | ISSN (online): 2579-6437

DOI: https://doi.org/10.46899/jeps.v8i2.230

\title{
FACTORS CAUSING NON-PERFORMING MURABAHAH FINANCING IN COOPERATIVE JASA \\ LKMS RISALATUNA \\ PADANG CITY
}

\section{Muhammad Ansharuddin Al Furqani ${ }^{1}$, Firmansyah ${ }^{2}$}

${ }^{1}$ SEBI: Email: furqon.muhammad1@gmail.com

${ }^{2}$ SEBI Lecturer Email : firms134@gmail.com

\begin{abstract}
This study aims to see the factors that cause murabahah financing to be non-performing financing. This type of research uses a qualitative descriptive method using literature study data. The results of the study are the factors that cause Nonperforming financing murabahah financing in the Risalatuna Jasa Cooperative in Padang City due to the Risalatuna Jasa Cooperative (internal factors) and the customers themselves (external factors). The Islamic law review of the settlement of Nonperforming financing murabahah financing at the Risalatuna LKMS Jasa Cooperative is following the principles of Islamic law, because in handling Non-performing financing, the Cooperative Jasa Risalatuna LKMS takes precedence first, providing facilities and debt relief.
\end{abstract}

Keywords: Murabahah contract, Non-Performing Financing, Cooperatives, Risalatuna LKMS Jasa.

\section{INTRODUCTION}

Cooperatives are economic institutions of the people. According to Law No. 25 of 1992 on cooperatives, in Chapter I, Article I, Paragraph 1 it is stated that cooperatives are business entities consisting of people or legal entities based on cooperative principle activities as well as people's economic movements based on kinship principles. The development of sharia cooperative history in Indonesia can not be separated from the development of the Islamic economy in the country. However, the movement of Islamic economic movements has existed since 1905. The development of the Islamic economic movement began to rise back in the 1980s, marked by the establishment of Baitut Tamwil Teknosa in Bandung, then followed by Baitut Tamwil Ridho Gusti in Jakarta but both institutions could not last long.

The establishment of BMT was able to provide alternatives for the economy of the people belonging to the grassroots level, especially small entrepreneurs (microbusiness). It is only a Non-Governmental Group (KSM) operating based on sharia, but BMT has a working system like a bank. Grouped BMT as KSM, at the time it was a strategy to avoid BMT from legal entanglement as a dark bank. Therefore, law No. 7 of 1992 on Banking states that: "Everything in the form of community fundraising in the form of savings and channeling in the form of credit must be in the form of banks" (Buchori, Sharia Cooperative Management, 2019) 
At that time, the BMT was growing rapidly, especially after several Non-Governmental Development Institutions (LSPM) participated in encouraging the establishment of KSM BMT, such as the Center for Education and Development of Small Businesses (P3UK) as the initiator, the Small Business Incubation Center (Pinbuk) initiated by the Indonesian Muslim Scholars Association (ICMI) and the Sharia Economic Forum (FES) initiated by Dompet Dhuafa Republika. All LPSM also helped develop Indonesia's economic system through its role by facilitating the distribution of financing funds from Bank Muamalat Indonesia (BMI), which was the only Sharia Commercial Bank (BUS) at the time. Besides being a facilitator, the LPSM assists in improving the skills of BMT human resources through various exercises. Furthermore, in 1994, the establishment of a Communication Forum (Forkom) BMT in Jabodetabek area which has members of BMT-BMT in Jakarta and chaired by Efendi Syarief from BMT Ikhtiro in Depok. One of Forkom BMT's efforts is to seek legal efforts for BMT. Thus, the idea of establishing BMT with sharia cooperative legal entities emerged. So this was also the hope of the Cooperative Department at that time so that all BMT incorporated cooperatives. At that time most of the BMT began to create cooperative legal entities. However, the type of Cooperative Legal Entity chosen is the type of Cooperative Employees Foundation by first establishing the Deed of Foundation. BMT that was established at that time had a cooperative philosophy because BMT has a base of economic activities of the people and philosophy: From Members, By Members, To Members. Therefore, based on Law No. 25 of 1992 on Cooperatives, BMT has the right to use cooperative law bada.

Sharia Financial Services Cooperative (KJKS) through the decree of the Minister of Cooperatives No. 91/Kep/M.KUKM/IX/2004 concerning Guidelines for the Implementation of Sharia Financial Services Cooperatives. Judging from the many existing muamalah agreements, such as rental services contracts, mortgages, and buying and selling in cash (bai' al musawamah), does not close the possibility of sharia cooperatives can be in the form of MultiBusiness Cooperatives (KSU). Member financing business activities in the form of cashless are categorized as Unit Simpan Pinjam (USP) or based on ministerial decree mentioned above called Sharia Financing Savings And Loan Unit (USPPS) which is a unit of KSU Syariah. To seek the strengthening of sharia cooperatives, the government continues to issue various regulations. Starting in 2004 with the release of the Ministerial Decree on the implementation instructions and then the rule of law is described in the form of implementation (juklak) and Standard Operating Procedures (SOP) and Standard Operational Management (SOM). Then, came the Regulation of the Minister of Cooperatives and Small and Medium Enterprises 35.2/Per/M.KUKM/X/2007 concerning Guidelines for Operational Standards of Management of Sharia Financial Services Cooperatives, Regulation of the Minister of Cooperatives and Small and Medium Enterprises 35.3/Per/M.KUKM/X/2007 concerning Guidelines for Health Assessment of Cooperative Sharia Cooperatives, and Regulation of the Minister of State of Cooperatives and Medium And Small Businesses 39/Per/M.KUKM/XII/2007 concerning Guidelines for Supervision of Sharia 
Jurnal Ekonomi dan Perbankan Syariah

Vol. 8. No.2, 0ktober 2020: 5-21, ISSN (cet): 2355-1755 | ISSN (online): 2579-6437 | 93

Financial Cooperatives and Sharia Financing Savings Units of Cooperatives. Then in 2012 appeared Law No. 17 of 2012 on Cooperatives the result of amendments to Law No. 25 of 1992, but it did not last long in which the Constitutional Court granted a judicial review lawsuit over several articles in Law No. 17 of 2012 on Cooperatives. One of the reasons is because the spirit is the spirit of the corporation not the cooperative, has eliminated the principle of kinship that is characteristic of cooperatives.

Furthermore, in 2015, the Regulation of the Minister of Cooperatives and MSMEs No. 16/Per/M.KUKM/IX/2015 concerning the Implementation of Sharia Savings and Financing Activities by Cooperatives was issued. Since the issuance of the regulation, the name of the nomenclature that was originally The Sharia Financial Services Cooperative (KJKS) changed to Cooperative Sharia Financing (KSPPS) and Sharia Service Unit (KSPPS/BMT) changed to Sharia Financing Savings Unit (USPPS). So the purpose of cooperatives based on the Law is to advance members and communities with economic movements to create the welfare of the people, as well as participate in the development of a fair and prosperous national economy based on Pancasila and the 1945 Constitution.

Non-performing financing is one of the big risks present in every banking world be it conventional banks, Sharia banks, even cooperatives, or BMT. Non-performing financing also gives a bad impact on BMT. One of the impacts is the unrepaid financing of some or all of them. The higher the problem financing, the worse the health of BMT liquidity. And it also affects the level of trust of the depositors who give their funds. Therefore, it is important to prepare the appropriate stages in which handling of non-performing financing is needed as a step to fix and improve the balance sheet. It is also necessary to be vigilant as early as possible in anticipation of unwanted things in the future.

In providing financing, KJKS implements financing procedures effectively, has a written policy on financing policies and receivables. Financing and receivable policies under KJKS's financial condition, as well as providing written documents on receivables and financing schedules. In financing is also an applied collateral system, where each financing provided is supported by the collateral of equal or greater value than the financing provided except financing for members up to Rp1,000,000 (one million rupiahs). This illustrates KJKS taking its decision based on the principle of prudence. The decision to provide financing and or placement of funds is outlined in the committee meeting.

After the financing is provided KJKS monitors the use of financing as well as mudharib's ability and compliance in fulfilling its obligations. Monitoring of financing is recorded in the monitoring report. KJKS conducts reviews, assessments, and bindings on its collateral. In the activities of binding andor submitting documents, it is stated in written documents. In terms of financing, members are required to comply in returning loans, so that the owner of KJKS members can increase KJKS capital under applicable regulations. For bad financing or non-performing financing, KJKS can charge at least 1/3 of last year's bad financing. For prudence, KJKS creates a reserve fund for the elimination of financing equal to or greater than the amount of annual bad 
financing. The reserve policy on the elimination of financing and nonperforming receivables are written into the policy and is outlined in the report.

Since this cooperative was established in 2013 until now, with this independent study, the opportunity to see how the factors causing Nonperforming financing in Cooperative Jasa LKMS Padang that focuses on murabahah financing, thus can see how the development of this Risalatuna financing.

\section{LITERATURE REVIEW}

\subsection{MURABAHAH}

According to M. Syafi'i Antonio contained in his book defines Murabahah is buying and selling goods at the original price with additional agreed profits. In this case, the seller must give the principal of the product he purchased and determine a level of profit besides, determining the length of the financing and the number of installments to be phased in (Antonio). Fiqh is a contract to buy and sell certain goods, where the seller mentions the goods traded including the purchase price of goods to the buyer, then he requires a certain amount of profit.

Murabahah is one of the fund distribution products in the interest of BMT because its character is profitable, easy to implement, BMT acts as a buyer as well as seller of certain halal goods needed by customers. First BMT buys goods to third parties at a certain price, directly or can be through a designated representative, for the next the goods are sold to customers at a certain price that has been added to the mark-up that has been mutually agreed from the beginning. The amount of income taken by BMT for murabahah transactions is constant, in the sense that it does not develop and does not decrease, and is not related especially by fluctuations in the rupiah exchange rate against the dollar (Wiroso, 2005).

While Adiwarman A. Karim in his book means that murabahah is " a sale of goods that are worth the goods plus agreed profits". For example, a person buys an item and then sells it for a certain profit. How much profit can be expressed in nominal rupiah or the form of a percentage of the purchase price, for example, $15 \%$ or $25 \%$ (Adiwarman Karim, 2007).

Zainul Arifin in his book explained that in murabahah transactions, the seller must mention the goods sold and the profits are taken, and how to pay them must be mentioned clearly. In this way, the buyer can know the actual price of the goods purchased and desired by the seller ( Zainul Arifin, 2006). From the understanding of murabahah, both in the literature of fiqh and banking practitioners can be concluded that the understanding of murabahah is a contract to buy and sell goods between sellers (BMT) and buyers (customers) with the facility of delaying payment for both the purchase of working capital assets and investments at the original price coupled with the profit and period agreed by both parties and the way the payment can be made at once (cash) at maturity or with installments. 
Jurnal Ekonomi dan Perbankan Syariah

Vol. 8. No.2, 0ktober 2020: 5-21, ISSN (cet): 2355-1755 | ISSN (online): 2579-6437

\section{5}

\subsection{LEGAL BASIS}

The Qur'an makes no direct reference to murabahah even though there are references to transaction, trade, profit, and loss. Similarly to the hadith, there seems to be no hadith that refers to murabahah directly (Abddullah Saed).

a) Qur'an Surah An-Nisa : 2

"Hi believers, do not consume each other's properties in a batil way, except with the path of business that happens just as much as you like. And do not kill yourselves; Indeed, Allah is Most Compassionate to you. (An-Nisa: 29).

This verse explains the law of transactions globally and more specifically the buying and selling transactions, where Allah SWT affirms the legality and ability to buy and sell in general and rejects and prohibits the concept of usury. Based on these provisions, murabahah buying and selling, especially obtaining legal recognition from Sharia and allowed to be used in financing practices in Sharia banks and other Islamic financial institutions because murabahah does not include buying and selling containing usury.

b) Hadith Ahmad History Number 15276

"From Jumai' bin Umair from his uncle the Prophet was asked about the most important income. He said: "The best income is a legitimate trade, there is no element of fraud and one's business with his hands." I'm sorry, I'm sorry. Ahmad No. 15276).

In the hadeeth explained about murabahah, where it is explained that it is permissible to buy and sell and considered valid if in the trade there is no element to deceive someone or anything else that can make the sale invalid itself, for example, goods sold fall into the category of illicit goods.

c) Ijma'

Muslims have agreed on the validity of buying and selling because human beings as social beings always need other individuals to meet their daily needs, therefore buying and selling is one way to bridge legitimately and voluntarily, so that everyone can meet their needs easily.

d) Indonesian law

1. The Law

The legal basis of murabahah was first regulated in Article 1 number 13 of Law No. 10 the Year 1998 concerning Amendment to Law No. 7 of 1992 on Banking.11 The regulation specifically contained in Law No. 21 of 2008 on Sharia Banking provides a definition of murabahah in explanation of article 19 paragraph (1) letter d. According to the explanation of the article referred to murabahah agreement is the financing agreement of an item by affirming the purchase price to the buyer and the buyer pays a higher price as an agreed profit (Sutan Remy Sjahdeni, 2014). 
96 | Muhammad Ansharuddin Al Furqani, Firmansyah: Factors Causing Non-Performing Murabahah Financing In Cooperative Jasa LKMS Risalatuna Padang City

\section{National Sharia Council (DSN)}

The National Sharia Council is a Council established by the Indonesian Ulama Council to deal with issues related to the activities of sharia financial institutions (Ahmad Ifham Sholihin, 2010).

According to fatwa DSN No. 04/DSNMUI/IV/2000 on April 1, 2000, which essentially states that to help the community to carry out and improve welfare and share activities, Sharia banks need to have murabahah facilities for those who need it, namely selling an item by affirming its purchase price to its payers at a price more as a profit (Khotibul Imam).

There are several other DSN-MUI Fatwas relating to murabahah agreements which are to become references and guidelines in determining the validity of the agreement, among others (Ahmad Sholihin, 2010): Fatwa DSN-MUI No. 04/DSN-MUI/IV/2000 on Murabahah, Fatwa DSN-MUI No. 48/DSN-MUI/II/2005 on Rescheduling, Fatwa DSN-MUI No. 46/DSN-MUI/II/2005 on Murabahah BillDeduction, Fatwa DSN-MUI No. 47/DSNMUI/II/2005 on Settlement of MurabahahReceivables for Customers Unable to pay, Fatwa DSN-MUI No. 23/DSN-MUI/III/2002 on Settlement Deductions in Murabahah, Fatwa DSN-MUI No. 17/DSNMUI/IX/2002 2000 on Sanctions on CapableCustomers Who DelayPayments, Fatwa DSN-MUI No. 13/DSN-MUI/IX/2000 on Down Payments in Murabahah, Fatwa DSN-MUI No. 16/DSNMUI/IX/2000 on Discounts in Murbahah.

\subsection{FINANCING}

In general, financing is used to defy the funding provided by Sharia institutions such as Sharia Banks to their customers. Financing is broadly financing or spending that is funding that is issued to support investments that have been planned, both done alone and done by others (Edi Susilo, 2017).

According to Antonio Syafi'i, financing is one of the main tasks in which the bank as the funder to meet the needs of parties who are deficit units or parties who are underfunded. Meanwhile, financing based on Sharia principles is determined based on the provisions of Bank Indonesia (Article 1 Number 25 of Law No. 21 of 2008 on Sharia Banking) namely:

" Provision of funds or bills equated with it in the form of a. transactions for the distribution of proceeds in the form of mudharabah and musyarakah; b. lease transactions in the form of ijarah muntahiya bittamblik; c. buying and selling transactions in the form of murabahah receivables, greetings, and istisna'; d. borrowing transactions in the form of qard receivables; and e. rental transactions of services in the form of ijarah for multi-purpose transactions, based on agreements and agreements between Sharia Banks and or Sharia Business units (UUS) and other parties required by the financed parties and or given financial facilities to return the funds after a certain period in exchange for ujrah, without reward, or profit share" (Law No.21 of 2008 Article 1 Number 25 concerning Sharia Banking). 
Jurnal Ekonomi dan Perbankan Syariah

Vol. 8. No.2, 0ktober 2020: 5-21, ISSN (cet): 2355-1755 | ISSN (online): 2579-6437

$\mathbf{9 7}$

Financing is the activity of Sharia banks in disbursing funds to other parties other than banks based on sharia principles. The distribution of funds in the form of financing is based on the trust given by the fund owner to the fund users. The owner of the fund believes to the recipient of the funds, that the funds in the form of financing provided will certainly be paid in full under the period agreed in the financing agreement.

The financing provided by sharia banks is different from the credit provided by conventional banks. In Sharia banking, the return on financing is not in the form of interest, but in other forms following the agreement provided in sharia banks. The term credit in sharia banking wins is unknown and used, because Sharia banks have different schemes than conventional banks in channeling their funds to customers in the form of financing, and the nature of financing is not a debt receivable but an investment given by the bank to the customer in conducting business. The existence of financing applied in Sharia banking is regulated in Banking Law No. 10 of 1998, where financing is the provision of money or bills that can be equated with it, based on the agreement or agreement between the bank and other parties financed to return the money or bill after a certain period in exchange or profit share. Financing provided by Sharia banking to fund users or customers based on sharia principles and rules under Islamic law.

\subsection{ELEMENTS OF FINANCING}

Financing is provided based on trust. Thus, the provision of financing is the granting of trust. This means that the achievements given must be believed to be refundable by the borrower by the time and terms agreed together. Based on this, the elements in the financing include:

1. There are two parties, namely the lender and the recipient of the financing.

2. Trust, namely the confidence of the lender that the recipient is following the period and terms agreed by both parties.

3. An agreement, i.e. an agreement between the lender and the recipient of the financing.

4. The period, i.e. the repayment period of the agreed loan.

5. Risk, namely the existence of a repayment grace period will cause a risk of non-collectible financing (non-performing loan).

6. Reciprocal is the advantage of providing a loan, such services that we will commonly know with profit or margin share (Pustaka Review, 2014).

\subsection{FINANCING ASSESSMENT}

An analysis process was conducted by sharia banks to assess a financing application that has been done by prospective customers. After analyzing the financing application, Sharia banks will gain confidence that the project will be feasible (Ismail, 2011).

The financing analysis based on $5 \mathrm{C}$ principles are:

12. Character ( personality or behavior)

Describe the character and personality of prospective customers. The Bank needs to analyze the behavior of prospective customers to know that prospective customers have the willingness to fulfill the obligation to repay the 
financing that has been received until it is paid off. The Bank wants to believe in willingness to replay from prospective customers, namely the bank's belief in the desire of prospective customers to meet obligations under the agreed timeframe. The Bank wants to know that prospective customers have an honest, good character, and have a commitment to repayment of financing.

13. Capacity

Analysis in this capacity is intended to know the financial ability of prospective customers were in fulfilling their obligations by the financing period. Banks also need to know with certainty the financial ability of prospective customers in fulfilling their obligations after sharia banks provide financing. The financial capability of prospective customers is very necessary because it is the main source of payment. The better the financial capability of prospective customers, the better the possibility of financing quality, meaning that the financing provided by Sharia banks can be paid with the promised time.

Some ways that can be taken in knowing the financial capabilities of prospective customers include:

1. View financial statements;

2. Check payslips and savings accounts;

3. Survey the location of prospective customers.

1. Capital ( wealth or assets)

Capital is required in the financing object where more in-depth analysis is carried out. Capital is the amount of wealth owned by prospective customers or the number of funds included in the project financed. The greater the capital owned and also by prospective customers in the financing object will be more convincing for the bank of the seriousness of prospective customers applying for financing and repayment.

\section{Collateral}

That is the guarantee provided by prospective customers for the proposed financing. The guarantee is the second source of payment. If the customer is unable to pay the installments, sharia banks can sell the guarantee. The proceeds from the sale of collateral are used as a second source of payment to pay off the financing.

The Bank will not provide financing that exceeds the value of collateral, except for certain financing that is guaranteed by certain parties. In the analysis of collateral, an important factor and must be considered is after-sales of collateral handed over to the bank. Sharia banks must be aware of the market interest in collateral handed over by prospective customers. If the guarantee is a marketable item, then the bank is confident that the collateral handed over by prospective customers is easy to sell. Financing that is closed by after-sales collateral will get a low risk as well.

In detail consideration of collateral are:

1. Marketability is a guarantee received by banks should be easy collateral to be traded at attractive prices and increase over time.

2. Stability of value is collateral handed over by the bank has a stable price so that when collateral is sold, the proceeds from the sale can replace the 
Jurnal Ekonomi dan Perbankan Syariah

Vol. 8. No.2, 0ktober 2020: 5-21, ISSN (cet): 2355-1755 | ISSN (online): 2579-6437

99

debtor's obligations.

3. Ascertainability of value is a guarantee that is accepted to have a more certain price standard.

4. Transferability is collateral provided by the bank is easy to transfer and easy to move from one place to another.

\section{Condition of Economy}

Analysis of economic conditions, the bank also considers the business sector of prospective customers is associated with economic conditions to the business of prospective customers in the future, to find out the economic condition of prospective businesses of prospective customers.

The principle of 5C, every financing application, has been analyzed indepth so that the results of the analysis are adequate. In the $5 \mathrm{C}$ analysis conducted effectively, it can be used as the basis for deciding the application for financing. Analysis of $5 \mathrm{C}$ needs to be done in its entirety.

\section{RESEARCH METHODOLOGY}

In this study, using descriptive research method through a qualitative approach where in this research to understand phenomena experienced by research subjects such as perception, behavior, action, etc.. (Moleong, 2010). This research can also be done by describing situations or events. (Sumadi Suryabrata, 18: 2002). The phenomenon is related to the factors that are the cause of Non-performing financing murabahah financing in Cooperative Jasa LKMS Risalatuna. Then the next will tower the finding in the form of a word or language as a whole. Furthermore, the phenomenon is formulated in the form of words or language as a whole.

\section{DISCUSSION}

This Service Cooperative started as one of the units in Kopontren Barokah Waqaf Arrisalah Foundation, namely the Save And Borrow Unit. Seeing the promising prospects, finally, this savings and loan unit separated itself from its parent Kopontren Barokah, to be managed properly and more professionally. So that right in April 2013, the cooperative officially established itself under the name Risalatuna Sharia Financial Services Cooperative.

The cooperative started operations with 92 members and increased to 155 members as of December 2013. Although not yet incorporated, KJKS Risalatuna still runs while preparing materials to register to become a registered and incorporated institution. So that in 2015, KJKS Risalatuna managed to get a deed of establishment on May 15, 2015, a Business License save and borrow from the Office of Cooperatives and MSMEs Padang city on June 22, 2015, and the Ratification of the Deed of Establishment of Cooperatives from the State Minister of Cooperatives and MSMEs also on the same date.

KJKS Risalatuna held its Preliminary Meeting in April 2014, with 161 members. It Started an annual meeting on March 26, 2015, for the 2014 book year, with 202 members. 
On December 2, 2016, KJKS made changes, namely; Changes in the name and type of cooperatives, changes to the Deed of Establishment of Cooperatives, and changes in management and supervisors. The Ministry of Cooperatives and MSMEs issued a letter ratifying the Amendment of the AD/ART of the Risalatuna Sharia Financial Services Cooperative to the Risalatuna Sharia Micro Finance Institution Services Cooperative. Signed by the Minister of Cooperatives and MSMEs on February 17, 2017. So now this cooperative is known as Cooperative Jasa LKMS Risalatuna.

\section{1 FACTORS CAUSING NON-PERFORMING FINANCING}

In non-performing financing, some factors cause the financing to become Non-performing financing. (Afif, 2014), explained that two factors cause Non-performing financing, namely internal and external factors. Internal factors are factors derived from Cooperative Jasa LKMS Padang and external factors that come from outside the management power or from members. According to (Astuti, 2015), the factors that cause the occurrence of Nonperforming financing from external parties, namely the absence of good faith from the members to pay the cost of obligations, members experience failure in managing their business, market aspects are less supportive, the public is less interested in buying the goods, there are constraints through government policies, misuse of funds by members (Kina, 2017).

While from the internal side, the factors that cause Non-performing financing include poor or bad management, incomplete financial statements, poor planning, competition between financing institutions, analysis of member fund needs conducted from sharia banks or bmt is not appropriate (Shobirin, 2016), and calculation of the amount of financing capital is not based on the type of member business (Kina, 2017). From the explanation above, it can be explained that the emergence of Non-performing financing in a financing institution is caused by two factors, namely from the member or recipient of funds that intentionally or unintentionally do not meet their obligations to pay installments, or not the development of businesses run by the Cooperative Jasa LKMS Risalatuna Padang City as the owner of funds that are less selective in providing financing to its members.

According to (Turmudi, 2016), these non-performing financing factors can be recognized through the symptoms that occur that cause Non-performing financing. The symptoms are similar to deviations in the provisions of the agreed agreement, non-thoroughness in presenting input materials, the company's weakening financial condition, and the declining value of goods used as collateral. Therefore, the factors that cause the emergence of non-performing financing should be immediately realized by the Cooperative Services Risalatuna LKMS Padang City so that it can directly take countermeasures by preventing or anticipating by creating or designing risk management to overcome the problem financing that is happening properly and correctly. 
Jurnal Ekonomi dan Perbankan Syariah

Vol. 8. No.2, 0ktober 2020: 5-21, ISSN (cet): 2355-1755 | ISSN (online): 2579-6437 101

During the financing period, there may be a financing condition where there is the first deviation in terms of payment resulting in a delay in payment or required juridical action in the return or poverty of potential loss. This situation is called non-performing financing, the condition of the decline in the quality of financing does not occur suddenly but always provides a "warning sign" or previous causal factors in financing. Several factors cause Non-performing financing where the causes of Non-performing financing arise from Cooperative Jasa Risalatuna, the customer, and external parties including the following:

a. Internal factors (derived from Cooperative Jasa Risalatuna LKMS)

1. The occurrence of mental erosion: conditions, where influenced by reciprocity between customers and cooperative members due to the financing process, is not by healthy banking practices and in practice is not fully by sharia principles, this will adversely affect the MFIS when the difference between buying and selling murabahah and riba. 
TABLE3.1 RIBA AND MURABAHAH LOANS

\begin{tabular}{|c|c|c|}
\hline No & Banks & Murabahah Not Cash \\
\hline 1 & $\begin{array}{l}\text { Giving money on the } \\
\text { condition that it pays off and } \\
\text { gives additional, } \\
\text { punishment is unlawful. }\end{array}$ & $\begin{array}{l}\text { Akad murabahah does not } \\
\text { include the sale and purchase } \\
\text { of credit, which is } \\
\text { permissible to take advantage } \\
\text { as desired, and the law is } \\
\text { lawful. }\end{array}$ \\
\hline 2 & $\begin{array}{l}\text { Interest on debt derived } \\
\text { from financial financing i.e. } \\
\text { exchanges money in } \\
\text { cashless terms. }\end{array}$ & $\begin{array}{l}\text { The profit on the sale of } \\
\text { credit murabahah comes } \\
\text { from the financing of goods, } \\
\text { i.e. goods exchanged for } \\
\text { money. }\end{array}$ \\
\hline 3 & $\begin{array}{l}\text { In the usury contract, there } \\
\text { is no money turnover, there } \\
\text { is only giving birth to } \\
\text { money. }\end{array}$ & $\begin{array}{l}\text { In the sale of credit, there is } \\
\text { a turnover of money, } \\
\text { because the money is bought } \\
\text { goods and then resold into } \\
\text { money. It becomes the } \\
\text { wheels of the economy } \\
\text { spinning and the property is } \\
\text { not monopolized only by the } \\
\text { owner of the capital. }\end{array}$ \\
\hline 4 & $\begin{array}{l}\text { Interest debt is the main } \\
\text { cause of inflation because } \\
\text { the increase in the amount of } \\
\text { money in circulation is not } \\
\text { followed by the increase in } \\
\text { goods and services. }\end{array}$ & $\begin{array}{l}\text { In murabahah on credit, the } \\
\text { amount of money disbursed } \\
\text { is accompanied by the } \\
\text { increase in goods and } \\
\text { services in real terms. }\end{array}$ \\
\hline
\end{tabular}

Source: fatwa lajnah daimah, vol. Xiii, p. 148-149

2. Sales projects do not take into account business habits and lack of accounting for the competitor aspect, which in sales should look at the marketing that is on the rise so that we can see how our sales competition against others. Implementation of Segmentation, Targeting, and Positioning of KJKS Risalatuna 


\section{3}

\section{a. Segmentation}

To achieve optimal marketing results, the first thing that must be done first by a company is to segment the market. Market segmentation is an effort to improve the accuracy of goal setting of a company. A company before starting its business must determine the segmentation of its consumers. Because buyers generally differ from each other in the market, both in motive and behavior and in their purchasing habits all of which indicate that the market of a product is not homogeneous, but heterogeneous in fact. On this basis, companies should group consumers into groups with the same characteristics or traits. Market segmentation essentially divides market potential into specific parts; can be based on demographic divisions; based on economy and education classes or also based on lifestyle or psychographic (Swastha, 2008).

The segmentation carried out by risalatuna MFIS by only segmenting based on residence, income level, and personality according to the author is appropriate. This is done so that its service products will be easily marketed by marketing and more controlled. So that marketing activities can run more effectively and efficiently. By implementing this market segmentation, marketing activities can be carried out more targeted and MFIS resources in the marketing field can be used more effectively and efficiently and can allocate them to the most profitable potential customers. This is the basis for determining which marketing strategies will be executed for marketing objectives to be achieved.

\section{b. Targeting}

After the segmentation of the product has been determined, then the next step is to target or target the target market that the company has chosen in the analysis of market segmentation. Targeting is the activity of selecting and assessing one or more market segments to be entered (Tijptono, 2014). In this case, of course, a series of marketing programs that are carried out must fit the characteristics of the target market to be targeted. For the target market, LKMS Risalatuna Padang has determined who is the target. And of course, the target market of Risalatuna LKMS varies for each product. In this case, Risalatuna LKMS uses selective specialization in determining its marketing target, namely the company chooses several interesting market segments and by its objectives and resources. According to the author, the target market determination carried out by risalatuna MFIS is quite good, namely limiting the target market for financing products so that the possibility of bad loans arising from customers who do financing is very small. As for $1 \mathrm{kms}$ risalatuna savings products accept all levels of society. This will bring benefits for Cooperative Jasa Risalatuna that are getting as many customers as possible because of more and more customers or members of a Cooperative Services LKMS. Thus, the profit obtained is greater. Besides, KJLKMS Risalatuna also restricts the area that is the target market. This is done considering the limited resources owned by KJ LKMS Risalatuna which only has one marketing. Nevertheless, KJLKMS Risalatuna still has to expand its market share by not limiting the area that is the 
target market. This can be overcome by increasing the number of marketing KJLKMS Risalatuna Padang.

\section{c. Positioning}

To create its own impression and image in the minds of its consumers by expectations, KJLKMS Risalatuna socializes itself as a trusted and maslahah business partner, positioning itself as a financial institution whose main task is to raise public funds and channel to the community. So KJLKMS Risalatuna is the best solution to provide a variety of product and service facilities to the community by using a result-share system in a fast, practical and calming process and a flexible period.

The lack of thorough manager JKLKMS Risalatuna in analyzing financing guarantees such as customers applying for financing at JKLKMS Risalatuna amounting to Rp. 20,000,000, for the need to buy motorcycles in murabahah financing, where the contract used to buy and sell goods states the purchase price and profit (margin) agreed by the seller and buyer.

Murabahah financing practice is KJLKMS Risalatuna Padang as the position of seller and customer is the buyer. KJLKMS Risalatuna sells goods to customers for $\mathrm{Rp} 22,000,000$, with a breakdown of the basic price of $\mathrm{Rp}$ $20,000,000$ and a margin of $\mathrm{Rp} 2,000,000$, in this case, the customer uses the installment payment system or maturity with a period of 12 months and if specified then each month must deduct Rp 2,000,000. Before the proposed disbursement of financing, the customer must provide a guarantee as one of the conditions of fulfillment of this agreement, this guarantee has been determined by the KJLKMS that is to submit BPKB, and here the manager must analyze the BPKB whether it is true to have the owner of the customer and check back deeply so that when the customer is unable to carry out his obligations to gradually each month the KJLKMS has the right to withhold the guarantee.

To give firmness in giving orders to employees or staff KJLKMS Risalatuna so that there is no doubt in analyzing the financing guarantee and also provide relief such as entertainment so as not to tres in doing work because it also affects the performance if there is no entertainment, and motivate employees to make the performance become good KJLKMS Risalatuna do some things including by providing benefits, training, and bonuses to make employees KJLKMS Risalatuna can be more enthusiastic in carrying out their duties.

Through work motivation given to employees, KJLKMS Risalatuna will cause job satisfaction in employees. A person's satisfaction or dissatisfaction with work is subjective and is the result of a conclusion based on what the employee, desired, and thought of as appropriate, or entitled to. While each employee subjectively determines how the job can satisfy him or her. Job satisfaction is influenced by a social situation (Burhanuddin Yusuf, Human Resources Management in Islamic Financial Institutions, 2015). 
Job satisfaction is a pleasant or unpleasant emotional state in which employees view their work. Job satisfaction reflects a person's feelings for his work. This can be seen from the employee's positive attitude towards his work and everything faced in his work environment. Job satisfaction from the employee itself will affect his presence on the job, and the desire to move jobs can also affect his willingness to work.

An employee's willingness or motivation to work is usually indicated by constant, goal-oriented activities. Motivated employees are usually those whose behavior is directed towards organizational objectives and whose activities are not easily disrupted by minor disturbances. While unmotivated employees can be seen from employee behavior that does not show goal directed (goal-oriented), employee behavior that is not directed at goals of value to the organization, and employees are not committed to the goal, therefore employees are easily disturbed and demand high supervision.

Work motivation is not only given through materials but also nonmaterial, it is done so that employees feel cared for and appreciated, so that job satisfaction in employees will grow and they will exert their abilities in earnest for the company. By providing salaries alone it is not enough to increase employee work motivation, but also accompanied by benefits, bonuses, gifts, awards, and other facilities that can meet the needs of employees.

3. Lack of understanding of the customer's business, there are some customers when yes will run their business but do not understand the business in-depth such as fried chicken business a la KFC, so customers before running a business must know how to manage the fried chicken before the sale and whether the ingredients to be used can make the food can be a satisfaction to customers who will consume it, so customers must be guided intensively to understand and not make mistakes in doing something.

KJLKMS Risalatuna explained to the customer before the customer wants to run the business so that the customer understands whether the business run can make a profit and can return the capital that the customer has borrowed.

\section{b. External factors (from the customer)}

The cause of external factors of Non-performing financing is how the recipient members of the financing. This relates to how the character of the prospective financing recipient members and the streaming slide of the use of funds.

1. There is a government policy where the regulation of a product or economic or industrial sector can have a positive or negative impact on companies related to the industry. Government policy sometimes affects Nonperforming financing. One example is the policy of importing rice from abroad that causes the price of rice to fall in the market. While the cost of agricultural production becomes disproportionate to the selling price of its production. Other examples include government policy on fuel price instability. This will cause the producer to be overwhelmed determine the selling price of its production. 
2. The occurrence of natural disasters.

Natural disaster factors are the most difficult indicators of failure to predict. As earthquakes, floods, tsunamis, is some of the factors of Non-performing financing. This condition can be minimized by ensuring the life and assets owned. As the customer has done murabahah financing to buy a car with KJLKMS Risalatuna Padang within 1 year / 24 months, then in the middle of a natural disaster where the car was hit by a tree due to an earthquake then with a disaster caused by nature the customer can get insurance to replace the car. But even though the customer does not know when the disaster will approach there are still efforts not to be affected as well as avoid places where examples often flood, it must immediately evacuate and always be vigilant if the disaster that approaches the customer does not mean to give up so that the assets or goods owned are damaged to cause losses.

3. Unable to solve problems/lack of control of the business, so if there is a conflict in the business should be able to overcome the problem because if not able to overcome will be able to experience losses because it requires a solution. Before wanting to run a business or business offline or online customers must already know the basics of how to run a business and also observe whether the business if established can produce profits which must be thought carefully, can not just set up without any planning at all. So the customer must be guided to experts who have good knowledge of Sharia business so that they can channel their knowledge to customers who will become mudharib or who will manage the business so that it can be in sync with the business activities carried out. And if there is a mistake the customer is also able to overcome what causes his business can suffer losses and can overcome the problem so that the problem does not occur a second time.

4. The customer's business field is saturated, which when he opens a business that he founded is difficult or people are bored like any other business, then the business needs innovation to make the business not saturated. So that the business is not the same as others so customers need an open outbox thinking where the business is run differently from others to make consumers interested in new things because now the competition is very high so it requires a strategy so that the business has more advantages than other businesses. As we can see the reference of businesses that exist abroad and the business has not been applied in Indonesia then our opportunity to make the business but modified our version does not have to be the same as businesses that exist abroad so that with the established business we can bring up the peculiarities of Indonesia which makes consumers interested.

5. The business is still new, which is usually a business that requires patience if it is to earn more profit and it requires marketing for the business to run properly. It is natural in running a business that is just the beginning may initially not immediately get soaring profits to require stages for the business to develop. And need strategic assistance also so that the business run can develop well as businesses run in a month earn a profit of 5 million, eating the business manager must think so that how the business run in the next 5 months the revenue will be received per month not 5 million more but 10 


\section{7}

million. So the manager must turn his brain to be able to get the profit of 10 million, whether the concept is changed in terms of his place of business, goods sold, and so forth.

6. Customer management ability does not support so that it loses in business competition, in management should have skills so that how to manage the business well so that it can rival businesses out there. And customers are also guided so that the managed business can run well such as the management of catfish livestock business which requires a large pond so that it can accommodate many catfish there. As well as the management of catfish livestock requires skill also to be able to multiply the catfish which provides food regularly also replace the pond water to make catfish clean and healthy. So if the catfish farming is run properly then the catfish business will develop well.

7. Sidestreaming the use of funds.

The cause of Non-performing financing is the misuse of funds. Not a few financing members apply for financing to the Risalatuna LKMS Service Cooperative not only for their personal or business purposes but for the needs of others. This misuse of financing is difficult to detect if the principle of the prudence of the management of the Risalatuna LKMS Service Cooperative is not enforced. KJLKMS Risalatuna must check the identity of the customer care and his background before financing so as not to cause problems later on, and KJLKMS risalatuna has implemented the rule for every customer who will do financing.

8. The character of the customer is not trusted (dishonest in providing information and reports on its activities).

Character assessment is a quantitative aspect that can only be understood if we have known for a long time the prospective recipients of financing. This factor is the biggest factor that causes Non-performing financing because the highest rating of Non-performing financing causes is the character factor. Therefore, a financing officer or Account Officer must be observant of the character assessment of prospective borrowers. Because one's character is not enough just to be seen from one meeting. The financing party must also ascertain whether the prospective recipient of the financing is a credible person by asking neighbors, colleagues, and suppliers. This is done to anticipate the occurrence of Non-performing financing after the financing is provided.

\section{CONCLUSION}

Based on the research that has been done on "Non-performing financing Murabahah Financing Factors in the Risalatuna LKMS Service Cooperative in Padang City", it can be concluded the factors which cause non performing financing murabahah in the Cooperative Jasa Risalatuna LKMS Padang City due to the Cooperative (internal factors) and the customer such as: Decreased business income obtained by customers, customers experience bankruptcy and customers have difficulty in financing. So that it is handled by rescheduling, restructuring, loan offsets (collateral sales), and elimination of financing. 
108 | Muhammad Ansharuddin Al Furqani, Firmansyah: Factors Causing Non-Performing Murabahah Financing In Cooperative Jasa LKMS Risalatuna Padang City

\section{REFERENCES}

Abu Shanab, E., \& Pearson, J. . (2011). Internet banking in Jordan The Unified theory of acceptance and use of technology (UTAT) perspective, 1-6. https://doi.org/10.1108/EL-01-2014-0022

Adiwarman Karim, Islamic Bank of Fiqh and Financial Analysis, Jakarta: PT Raja Grafindo Persada, 2007, cet. 3rd, p. 3. 255.

Ahmad Ifham Sholihin, "General Guidelines of Sharia Financial Institutions", Jakarta: Gramedia Pustaka Utama, 2010, p. 51.

Edi Susilo, "Analysis of Financing and Risk of Sharia Banking", Yogyakarta: Student Library, pp. 117-119.

http://www.kajianpustaka.com/2014/02/pengertian-unsur-tujuan-jenispembiayaan.html

Ismail, Sharia Banking, Jakarta: Kencana Prenada Media Group, 2011,p. 119.

Cooperation of mui-Bank Indonesia National Sharia Council, Fatwa Association, p.20

Khotibul Imam, "Sharia Banking Basics and Dynamics of Its Development in Indonesia", Jakarta: PT. Grafindo Persada, p. 105106.

M.Luthfi Hamidi, Traces of Sharia Economy,Jakarta: Senayan Abadi Publishing, 2003, p.47

Moleong, Lexy J. 2010. Qualitative Research Methodology. Revised Edition. Bandung: PT. Rosda Works

Nur S. Buchori, Sharia Cooperative,East Java: Mashun, 2009, p. 2009. 10.

Sharia Banking in Indonesia Institutional and Policy And FutureChallenges, Depok: PT RajaGrafindo Persada, 2017, p.xx

Setiawan, Principles of The Law of Alliance, Bandung: Binacipta, 1979, p. 1979. 18

Suryabrata, Sumadi. 2002. Research Methodology. Jakarta : King Grafindo Persada

Sutan Remy Sjahdeini, "Sharia Banking Products and Legal Aspects", Jakarta: Prenamedia Group, 2014, p. 193.

Trisadini Prasastinah Usanti, "Characteristics of Prudential Principles in Sharia Banking Business Activities", Surabaya: Airlangga University, 2010, p. 100. 244

Law No. 21 of 2008 Article 1 Number 25 concerning Sharia Banking.

Wiroso, Buy Sell Murabahah, Yogyakarta: UII Press, 2005, p. 1

Zainul Arifin, Sharia Bank Management Basics, Jakarta: Pustaka Alvabet, 2006, cet. 4 th, p. 85 . 